\title{
Cross-border Previous Learning Recognition: Enhancing Lifelong Learning and Social Inclusion
}

\author{
Helena Cobos Rius ${ }^{1}$, Driss Boumeggoti ${ }^{2}$, Josep Fortó Areny ${ }^{3}$, Betlem Sabrià Bernadó ${ }^{4}$ \\ ${ }^{1}$ Research, Universitat d'Andorra, Andorra, ${ }^{2}$ Continuous Training, Université Toulouse Jean \\ Jaurès, France, ${ }^{3}$ Business School, Universitat d'Andorra, Andorra, ${ }^{4}$ Continuous Training, \\ Universitat d'Andorra, Andorra.
}

\begin{abstract}
Regarded as a social advancement tool, Previous Learning Recognition (RPL) processes' development in cross-border regions should enable the transferring of qualified and Higher Education graduated workforce across territories. Within the project LLL-Transversalis, French universities have been establishing RPL assessement events with international participants (Spanish and Andorran) in order to build a cross-border RPL system in the Pyrenees region. This paper exposes the characteristiques of these unique RPL processes and the results obtained. So far, eleven events have been developed, accrediting students in the domains of Engineering, Tourism and Management. Jurys were compounded on average of 7 members from both academic and professional worlds and observers from Spain and Andorra were present. Feedback from international participants is highly positive. Due to the economic and social crisis caused by Covid-19, cross-border and national RPL could turn out to be an effective way to galvanize human capital growth in the following years, hence the value of this project's actions. Taking advantage of mobility restrictions caused by the sanitary crisis, the first online cross-border RPL events will take place later this year, setting a starting point for further research and innovation on these practices in Spain and Andorra with the help of French institutions.
\end{abstract}

Keywords: Lifelong learning; assessment; recognition; previous; learning; cross-border. 


\section{Introduction}

Recognition of Previous Learning (RPL) or Previous Learning Assessment (PLA) are terms referring to the process of awarding institutional credit to knowledge and skills acquired through informal education or work experience (Browning, 2020; Harris \& Wihak, 2017; Kilgore, 2020; Morris \& Rust, 2020). As the International Labour Organization [ILO] (Aggarwal, 2015) reports, a considerable amount of people struggle to get access to certain jobs or occupations due to a lack of recognized qualifications. In a recent study called "Recognition of Previous Learning in the 21st Century", Leibrandt, Klein-Collins and Lane (2020:2) stated that "effective policies and practices on the recognition of prior learning have the potential to create more efficient pathways for economic mobility and increase student success and credential completion-especially for adults." Facing an unprecedented economical and social crisis, RPL processes can help people widen their professional expectations and thereby contribute to improve their mobility, social inclusion and employability. At the EU level, the adoption of the Memorandum on Lifelong Learning (LLL) set the Commission's main policy instrument to foster employability and economic growth (Bousquet, 2019). Consequently, 15 years ago, the European Council adopted the principles to identify and validate informal and non-formal learning from which followed the guidelines - published by the European Center for the Development of Vocational Education and Training (Cedefop) - for validating these types of learning (Cedefop, 2015). Ultimately, the motivation for adopting RPL systems in member states is based on an increased development of lifelong learning, a better employability and mobility, and the enhancement of economic growth and competiveness (CEU, 2012). Following the EU priorities, different cooperative programs are developed in order to foster Lifelong learning practices accross member states. The authors would like to highlight the Interreg V-A Spain-France-Andorra (POCTEFA 2014-2020) European cooperation program which aims at addressing the crossborder challenges linked to the Europe 2020 strategy in the Pyrenees border region. One of POCTEFA's axis is "Social inclusion and labour mobility" within and accross the territories. In order to achieve the goals set in this axis, a project called Lifelong Learning Transversalis was created. Based on historical cooperation (TRANSVERSALIS 2009-2013) between Higher Education Institutions, this project aims at harmonizing and strengthening practices of life-long learning and vocational training, committing itself to achieve the following goals: a) to bind skills and training offers, b) to implement successful orienation tools and c) to create and develop common training models and RPL processes adapted to the labour market's needs (INTERACT, 2021). Focusing on the last goal, two research questions were put forward: a) Which is the RPL approach in Higher Education in the Pyrenees border region? and b) What are the proceedings in order to establish cross-border RPL processes? This paper presents the answers to these questions in the following sections by reviewing the legal countries' status in this regard and describing an innovative RPL approach in Higher 
Education, in which either candidates or members of the jury come from different territories, members of the project LLL-Transversalis. Ultimately, deploying cross-border jurys should foster professional and student mobility as well as an improvement or changement in RPL processes in Spain and Andorra.

\section{Recognition of Previous Learning in the Pyrenees border region}

Regarded as a social advancement tool, RPL processes' development in cross-border regions should enable the transferring of qualified and HE graduated workforce across territories. Inequalities or differences between countries' RPL systems can hinder these exchanges (Croisille, 2012), hence the importance of knowing each territory's RPL approach in order to find a way of harmonizing the practices.

\subsection{RPL in Andorra}

Recognition of Previous Learning in Higher Education has not been developed yet in Andorra. The closest practice which exists in the University of Andorra is to validate an internship period thanks to professional experience if the latter is related to the training program (Bousquet, 2019). However, RPL processes in this country apply to Vocational Education and Training (VET) programs where students can validate some units and even obtain a diploma, by granting competences developed through professional experience the same value as those obtained through training (Govern d'Andorra, 2021).

\subsection{RPL in Spain}

Formalized in 2009, RPL in HE in Spain is still inexistant as it is conceived in other European countries such as France. Candidates can give credence to professional experience in order to enroll in a VET program or HE institutions (for candidates over 40 years old). Universities can also validate competency or learning units obtained through formal education but, in any case, this will let candidates obtain the whole diploma through recognition of previous learning (Gobierno de España, 2021). Additionally, RPL processes and HE institutions' requirements vary depending on the regions - given the Spanish decentralised governance approach - making RPL a complex and fragmented process withing the country (Bousquet, 2019).

\subsection{RPL in France}

Contrary to its southern neighbours, France has an extended tradition and experience in RPL in HE. First formalised in 1985, RPL was introduced in French decrees as a way to enable access or to resume previous HE studies through professional experience's validation. This step would lay the foundations for "The Social Modernization Law" (Loi de Modernisation Sociale in French), passed in 2002 which granted the individual right to experience 
recognition in the Education and Labour Code (Bousquet, 2019). That same year, the RPL Decree was approved thus authorizing candidates to partially or totally obtain a HE diploma through recognition of professional experience and non-formal learning outcomes. Thanks to their long experience and a solid legal framework, French universities have been able to offer, develop and adapt RPL processes according to candidates' needs and HE institutions' possibilities. That being said, after some years of legal stability in this regard, the French government introduced, in 2018, a law which fundamentally changed the way HE programs are to be conceived. Instead of organizing them in units of study, HE degrees have to be issued in competency blocks. Although still gradually applied, this law affects the way RPL processes are developed and how candidates prepare their dossiers (Bousquet, 2019). Bearing in mind that content-based programs mainly rely and depend on each territory's reality and/or tradition, the authors deem this change positive as working with competency blocks may facilitate cross-border comprehension on learning outcomes thereby fostering mobility and recognition of competency acquisition through non-formal education and professional experience.

\section{Cross-border RPL}

In the European level, during the last 10 years, only two projects can be highlighted regarding cross-border RPL experiences. Both were developed between 2011 and 2013 and involved France and its northern neighbours (Héroult, 2015). Since then, European cross-border RPL development has been fostered within LLL-Transversalis. Such practices aim at introducing the Spanish and Andorran partners to HE RPL processes, fostering cross-border mobility in the Pyrenees region and, ultimately, enabling social inclusion through international recognition and validation of prior learning. In this section, the second research question is answered by explaining the experiences carried out by the University of Toulouse Jean Jaures (UT2J) and University of Perpignan Via Domitia (UPDV). Their outcomes are shown, as well as some quantitative data regarding the process.

\subsection{RPL proceedings}

In order to establish a RPL process, there are some requirements that both the candidate and the institution offering the validation have to meet. On the one hand, the candidate has to prepare a dossier containing: a) the candidate's experience, b) the functions assumed and competencies acquired, c) case studies and d) supporting documents. Through these sections, the candidate must be able to evidence the connection between the competencies and learning outcomes acquired through professional experience or non-formal education and those present in the HE program targeted. On the other hand, the institution needs to establish the assessment comittee and foresee the candidate's need of tutoring or support in case the dossier is accepted in the RPL process. At UT2J, the assessment comittee or jury is composed of 
three professors-researchers and two active workers in the domain the candidate is applying. On the other hand, UPDV establishes larger juries, making no distinction between the participants. Also, both universities provide with an academic advisor who cannot be part of the jury and who advices and supports the candidate through the whole process. Finally, although it is not still a formalized participant, in some French universities - specially those members of the LLL-Transversalis project - there is a third party who assists in RPL processes; the observer. The observers can be people familiar with the validation process, interested in the field of study the candidate applies to and, or, stakeholders. However, they cannnot interefere in the jury's decision regarding the recognition (or not) of the candidate's prior learning. Figure 1 illustrates the participants in RPL events according to established guidelines within the project.

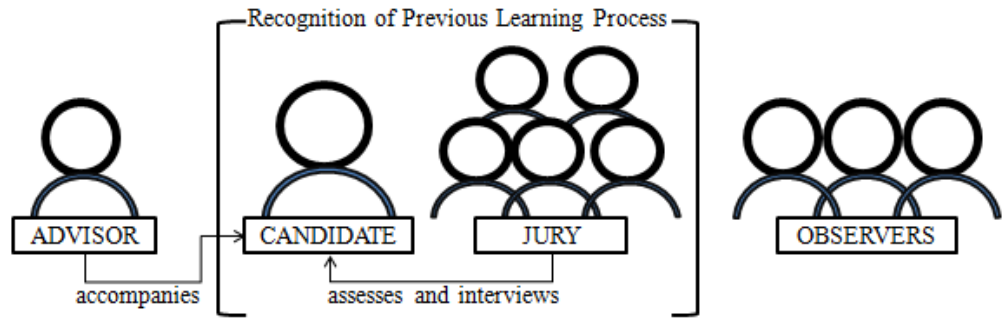

Figure 1. RPL assessment events' participants within LLL-Transversalis. Source: original.

\subsection{Methodology}

This was an action-based study in which quantitative and qualitative data was collected. The sole population requirement was that participants in the process were from different countries withing the Pyreenes border region. In order to limit the experience's scope, LLLTransversalis partners decided to focus on four professional domains in which develop these cross-border experiences: digital technology, agri-food, turism and metallurgy. Once the candidate's dossier accepted, the host university contacted cross-border professors and/or professionals within the field concerned, thanks to LLL-Transversalis partners' network and invited them to participate as observers. Although they could not directly influence the jury's decision, a report and qualitative feedback on the process was asked to them, thus providing with a complete minutes. Up to now, these people had to travel to France in order to attend the RPL assessment event. However, the last RPL events were hybrid as international participants were not able to travel due to Covid-19.

\subsection{Results}

So far, and during the last two years, eleven cross-border RPL jurys have been established and developed. In the following table (1), a synthesis of these cross-border RPL assessment processes is presented, including the territories involved, the diplomas targeted - Master's 
(M) or Bachelor (B) and the jury's decision, which could be a partial or total validation of the program chosen.

Table 1. Cross-border RPL assessment processes

\begin{tabular}{|c|c|c|c|c|c|c|}
\hline Date & Diploma & $\begin{array}{c}\text { Jury } \\
\text { (n) }\end{array}$ & $\begin{array}{l}\text { Observers } \\
\text { (n) }\end{array}$ & $\begin{array}{c}\text { Territories in } \\
\text { France and Spain }\end{array}$ & Method & Decision \\
\hline $29 / 06 / 19$ & $\begin{array}{l}\text { (M) Electronics and } \\
\text { electrical energy }\end{array}$ & 7 & 2 & Perpignan-Gerona & On-site & Total \\
\hline $25 / 09 / 19$ & (B) - Tourist Guide & 3 & 2 & Toulouse-Gerona & On-site & Total \\
\hline $25 / 09 / 19$ & (B) - Tourist Guide & 4 & 2 & Toulouse-Gerona & On-site & Total \\
\hline $25 / 09 / 19$ & (B) - Tourist Guide & 5 & 2 & Toulouse-Gerona & On-site & Total \\
\hline $25 / 09 / 19$ & (B) - Tourist Guide & 5 & 2 & Toulouse-Gerona & On-site & Total \\
\hline $18 / 09 / 19$ & $\begin{array}{l}\text { (M) Catering and } \\
\text { hotel management }\end{array}$ & 6 & 1 & Toulouse-Gerona & On-site & Total \\
\hline $18 / 09 / 19$ & $\begin{array}{l}\text { (M) Catering and } \\
\text { hotel management }\end{array}$ & 5 & 2 & Toulouse-Gerona & On-site & Total \\
\hline $18 / 09 / 19$ & $\begin{array}{l}\text { (M) Catering and } \\
\text { hotel management }\end{array}$ & 5 & 2 & Toulouse-Gerona & On-site & Total \\
\hline $17 / 06 / 20$ & $\begin{array}{l}\text { (B) Hotel } \\
\text { management }\end{array}$ & 10 & 2 & Perpignan-Gerona & Hybrid & Total \\
\hline $17 / 06 / 20$ & $\begin{array}{c}\text { (M) Touristic } \\
\text { heritage } \\
\text { management }\end{array}$ & 10 & 2 & Perpignan-Gerona & Hybrid & Total \\
\hline $17 / 06 / 20$ & $\begin{array}{l}\text { (B) Communication } \\
\text { and Tourism }\end{array}$ & 10 & 2 & Perpignan-Gerona & Hybrid & Total \\
\hline
\end{tabular}

A total of 36 people were mobilized and thanks to a strict filter process of candidates' dossiers, a $100 \%$ of the participants obtained a total validation of their previous knowledge, which meant the acquisiton of the complete diploma targeted. Also, a changement in the method chosen can be observed during the sanitary crisis which started in March 2020. So far, only a specific Spanish territory (Gerona) has been attending and participating to these cross-border RPL events. Feedback from international observers was so positive that other Andorran and Spanish partners have gained interest in participating in forthcoming RPL events - which will be held online, hence facilitating the assistance -.

\section{Conclusions}

Innovative and unique, these cross-border RPL jurys and assessment events could pioneer an active approach in which HE institutions in the Pyrenees region could benefit from shared practices and easier ways to enable professional mobility. The inclusion of international observers in RPL assessment events had already been tried in a similar experience, carried out within an European cooperation project in which Lituanian observers were invited to 
France, in order to get introduced to this practices (Bousquet, 2019). One of this project's asset and a key difference compared to previous experiences is that these cross-border RPL events are not a "one time" occurrence, which enables a constant improvement thanks to the feedback from the Spanish and Andorran observers. Additionally, given the advanced experience of French institutions in this field, such practices are a precious opportunity for Spanish and Andorran universities to become catalysts for change in their territories. Considering that neither of both [countries] have a formalized RPL system in HE yet, gaining experience through observation and gradually active participating in RPL jurys offer a chance to engage stakeholders and governmental agents, in addressing the need of established and clear RPL systems in Higher Education. Ultimately, these shared practices seek to create a RPL quality label valid in the Pyrenees region as to regulate and value social inclusion and mobility. Recognizing prior learning is acknowledged as a way to address issues related to lifelong learning, social inclusion and employment (Garnett \& Cavaye, 2015) and has been highlighted as a strategic priority to value people's contribution to society (Golden \& Gunn, 2020; Senséau \& Ansart, 2013). Due to the economic and social crisis caused by Covid-19, cross-border and national RPL could turn out to be an effective way to galvanize human capital growth in the following years, hence the value of this project's actions. To end on a positive note, amid rather negative consequences of the pandemic, the authors deem mobility restrictions an opportunity to implement cross-border RPL assessment events as online sessions which enable a growing international assistance. Consequently, the first online cross-border RPL events will take place later this year, in May, hopefully setting a starting point for further research and innovation on these practices in Spain and Andorra.

\section{References}

Aggarwal, A. (2015). Recognition of prior learning: Key success factors and the building blocks of an effective system. South Africa: International Labour Organization Publications.

Bousquet, J. (2019). Étude sur la Validation des Acquis et de l'Expérience en Europe. Université Toulouse Jean Jaurès: France. Retrieved from: https:/etransversalis.univperp.fr/medias/fichier/etude-vae-en-europe_1589803966627pdf?ID_FICHE $=66052 \& I N L I N E=$ FALSE

Browning, K. (2020). A Case Study on the Recognition of Prior Learning (RPL): Perceptions of University Faculty. The Canadian Journal for the Study of Adult Education, 32(1), 1540. Retrieved from: https://cjsae.library.dal.ca/index.php/cjsae/

Cedefop (2015). European guidelines for validating non-formal and informal learning. Luxembourg: Publications Office. Cedefop reference series; No 104. http://dx.doi.org/10.2801/008370

CEU. (2012). Council Recommendation of 20 December 2012 on the validation of nonformal and informal learning. Official Journal of the European Union, OJ No. C 398/1. Retrieved from: https://eur-lex.europa.eu/oj/direct-access.html 
Croisille, C. (2012). La validation des acquis de l'expérience en Allemagne, en France et au Luxembourg : Les obstacles à la mobilité. CRD EURES Lorraine: France. Retrieved from: https://www.frontaliers-grandest.eu/uploads/publications/livret-VAE-GR.pdf

Garnett, J \& Cavaye, A. (2015). Recognition of Prior Learning: Opportunities and Challenges for Higher Education. Journal of Work-Applied Management, 7(1), 28-37.

Gobierno de España. (2021, February 16). Acreditación de Competencias. Education Ministery. Retrieved from: https:/www.todofp.es/acreditacion-de-competencias.html

Golding, T. \& Dunn, C. (2020). Recognising Prior Experiential Learning: Challenges and Opportunities for Advancing Employability and Accrediting Lifelong Learning. In: Employability Conference 2020: expanding the narrative for a rapidly changing world, 11 Mar 2020, The Open University. Retrieved from: http://oro.open.ac.uk/69801/

Govern d'Andorra. (2021, February 16). Reconeixement $i$ Validació de l'Experiència Professional (RVEP). Education Ministery.

Harris, J. \& Wihak, C. (2017). To what extent do discipline, knowledge domain and curriculum affect the feasibility of the Recognition of Prior Learning (RPL) in higher education? International Journal of Lifelong Education, 59(4), 696-712. https://doi.org/10.1080/02601370.2017.1379564

Hérault, S. (2015). Reconnaissance et Validation des Compétences non-formelles et informelles en Europe : enjeux, systèmes, outils. Centreinffo: France. Retrieved from: https://www.ressources-de-la-formation.fr/doc_num_data.php?explnum_id=15010

INTERACT. (January, 2021). Life Long Learning - Transversalis. Retrived from: https://keep.eu/projects/20641/LIFE-LONG-LEARNING-TRANSVER-EN/

Kilgore, W. (2020). An Examination of Prior Learning Assessment Policy and Practice as Experienced by Academic Records Professionals and Students. Western Interstate Commission for Higher Education: United States. Retrieved from: https://files.eric.ed.gov/fulltext/ED607445.pdf

Leibrandt, S., Klein-Collins, R. \& Lane, P. (2020). Recognizing Prior Learning in the COVID-19 Era: Helping Displaced Workers and Students One Credit at a Time. Western Interstate Commission for Higher Education: United States. Retrieved from: https://files.eric.ed.gov/fulltext/ED607436.pdf

Morris, P. \& Rust, D. (2020). The State of Prior Learning Assessment in Graduate Education in the United States. The Journal of Continuing Higher Education, 68(1), 54-67. https://doi.org/10.1080/07377363.2020.1712625

Senséat, P. \& Ansart, S. (2013). Accreditation of Prior Learning as a Catalyst for Lifelong Learning: Analysis and Proposals Based on French Experiments. Journal of International Education Research, 9(4), 317-328. Retrieved from: https://core.ac.uk/reader/268113133 